\title{
PENGEMBANGAN SEKOLAH INKLUSI DAN PENGARUHNYA TERHADAP STRATEGI ASESMEN ANAK DIFABEL
}

\author{
Shofiyatuz Zahroh, Shohebul Umam \\ Universitas Islam Negeri Sunan Kalijaga Yogyakarat, Indonesia \\ email:shofi.zara@gmail.com, shohebul.umamjr@gmail.com
}

\begin{abstract}
:
The purpose of this study is to look at the implementation of the curriculum of children with special needs, strategies for assessing children with special needs, methods or strategies learning of children with special needs, and the concept of inclusive education. This research was conducted at Safa Islamic Preschool Yogyakarta, 2019 which developed the curriculum 2013 and combined it with a Montessori curriculum that breathed in Islam. The method research used was qualitative with a case study approach. The results of this study are, Safa Islamic Preschool really maintains the excitement of the education system inclusive, by making careful planning of the learning process and the assessment of children with special needs. Conclusion children with special needs are able to develop their potential well in accordance with the obstacles they have, shadow teacher is able to guide children in developing their potential, the environment is able to create situations that are very supportive of children's development, assessment is carried out in accordance with procedures with special needs.
\end{abstract}

Keywords: inclusion education, learning method or strategy, assessment, children with special needs

\begin{abstract}
Abstrak:
Tujuan penelitian ini adalah untuk melihat implementasi kurikulum terhadap anak berkebutuhan khusus, strategi penilaian anak berkebutuhan khusus, metode atau strategi pembelajaran anak berkebutuhan khusus, dan konsep pendidikan inklusi. Penelitian ini dilakukan di Safa Islamic Preschool Yogyakarta, 2019 yang mengembangkan kurikulum 2013 dan dikombinasikan dengan kurikulum Montessori yang bernafaskan Islam. Metode penelitian yang dilakukan adalah kualitatif dengan pendektakan studi kasus. Hasil dari penelitian ini adalah, Safa Islamic Preschool benar-benar menjaga marwah sistem pendidikan inklusi, dengan membuat perencanaan yang matang terhadap proses pembelajaran serta penilaian anak berkebutuhan khusus. Kesimpulan anak berkebutuhan khusus mampu mengembangkan potensinya dengan baik sesuai dengan hambatan yang dimilikinya, shadowteacher mampu membimbing anak dalam mengembangkan potensinya, lingkungan mampu menciptakan situasi yng sangatmendukung terhadap perkembangan anak, penilaian dilakukan sesuai dengan proseduranak berkebutuhan khusus.
\end{abstract}

Keywords: pendidikan inkklusi, metode atau strategi pembelajaran, penilaian, anak berkebutuhan khusus

\section{PENDAHULUAN}

Setiap anak dilahirkan dengan potensi-potensi bawaan yang melekat di dalam dirinya, namun tidak setiap anak mampu mengembangkan potensi tersebut menjadi bakat. Faktor internal dan faktor eksternal sebagai pemicu terbentuknya bakat anak. Sebagian anak mampu mengembangkan potensinya dengan berbagai SDA dan SDM yang ia miliki. Namun, sebagian lagi ada anak yang kurang mampu mengembangkan 
potensinya karena terhambat SDA ataupun SDM. Salah satunya adalah anak berkebutuhan khusus, walaupun mereka juga memiliki potensi yang bisa dikembangkan dalam dirinya, namun ada keterbatasan dalam pengembangannya, misalnya karena ganggunag fisik ataupun gangguan perkembangan seperti perhatian pendek, autisme dan lain sebagainya.

Ada banyak pakar yang memberikan pengertian terkait anak berkebutuhan khusus, salah satunya adalah Smart yang mengatakanbahwaanak berkebutuhan khusus adalah mereka yang memiliki karakteristik berbeda dari anak-anak secara umum, baik dari segi fisik ataupun mental(Smart 2006). Pengertian lain mengatakan bahwa anak berkebutuhan khusus adalah mereka yang memiliki kelainan atau ketunaan dalam segi mental, fisik, emosi dan sosialnya(Faradina 2016). Sehingga, anak mengalami hambatan dalam keberlangsungan hidupnya, dan membutuhkan pendamping dalam mengembangkan setiap aspek perkembangan yang akan dilalui oleh anak. Sedangkan dalam UU/8/2016/p1 anak berkebutuhan khusus atau difabel adalah mereka yang mengalami keterbatasan fisik, mental, sensorik ataupun intelekttual, baik dalam jangka waktu yang lama ataupun sebentar, yang mampu menghambat mereka dalam berinteraksi di lingkungan sosialnya serta tidak bisa berpartisipasi secara aktif sebagaimana yang lainnya(Undang-Undang 2016)

Namun dalam hal ini peneliti akan menggunakan istilah anak berkebutuhan khusus, merujuk kepada pengertian yang diberikan oleh Safa Islmaic Preschool, dimana istilah difabel dianggap sangat kasar serta berkonotasi negatif, yaitu anak-anak yang memang memiliki kelainan. Sehingga, anak berkebuuhan khusus atau ABK dianggap sangat tepat untuk menyebut mereka yang memiliki something spsial.

Berdasarkan pengertian di atas, maka Krick mengatakan bahwa anak berkebutuhan khusus adalah mereka yang mengalami penyimpangan dari segi mental, fisik ataupun sosial yang membutuhkan bantuan orang lain dalam mengembangkan potensi-potensi yang ada dalam dirinya(Efendi 2006). Sehingga, pendidikan inklusi menjadi sangat penting dalam kehidupan anak berkebutuhan khusus. Dengan adanya sekolah inklusi anak tidak termarjinalkan, baik dari segi pendidikan ataupun sosialnya. Hal ini karena anak mampu mendapatkan pendidikan semaksimal mungkin di dalam 
kelas reguler bersama teman-teman sebayanya, dan dengan shadow teacheryang siap mendampingi proses belajar anak selama di sekolah.

Pedidikan untuk anak difabel di Indonesia saat ini sudah mengalami perkembangan yang sangat pesat. Pada mulanya anak difabel di tempatkan di sekolahsekolah yang khusus anak difabel yaitu SLB (Sekolah Luar Biasa), dimana seluruh jenis difabel berada dalam satu atap sehingga memudahkan guru untuk membimbing anak dalam proses belajar mengajar. Hal ini diyakini snagat efektif untuk mengebangkan potensi-potensi yang dimiliki oleh anak difabel, karena mereka memiliki something spesial dalam dirinya yang tida dimiliki oleh aak normal lainnya. Kenyataan ini, sangat berbeda dengan Amerika Serikat (AS) yang mengeluarkan kebjakan pendidikan bahwa setiap anak berhak mendapatkan pendidikan yang sama, artinya anak difabel maupun anak noral berada dalam satu atap dalam proses pembelajaran, sistem yang demikian ini dikatakan inklusi (Suyanto 2005). Baru-baru ini, pemerintah Indonesia mengadopsi peraturan tersebut (PerMen Pendidikan Nasional RI/70/2009)dengan menganjurkan seluruh sekolah dari berbagai jenjang mulai PAUD, SD, SMP hingga PT untuk menciptakan lembaga pendidikan yang ramah difabel atau inklusi(Permen 2009).

Sekolah inklusi merupakan lembaga pendidikan yang siap untuk menerima peserta didik dalam kondisi apapun, baik anak normal maupun anak berkebeutuhan khusus dengan gangguan mental ataupun fisik. Sekolah merancang pendidikan yang layak, menantang dan menarik sesuai dengan kebutuhan anak, tanpa adanya deskriminasi(Wati 2014). Selain itu, sekolah juga mempersiapkan kebutuhan teknis untuk anak berkebutuhan khusus, seperti shadow teacher (guru pendamping), akses jalanan yang bisa dilalui anak yang memakai kursi roda serta permainan edukatif (APE) yang mendukung perkembangan anak berkebutuhan khusus.

Selain kebutuhan-kebutuhan teknis, sekolah juga harus mempersiapkan kurikulum serta metode pembelajaran yang tepat untuk anak berkebutuhan khusus. Serta indikator penilaian yang cocok untuk anak berkebutuhan khusus. Instrumen yang digunakan bersifat menyeluruh, artinya sama dengan anak normal lainnya, hanya saja indikatornya diturunkan, karena anak berkebutuhan khusus berbeda dengan anak normal lainnya. Seperti, dalam perkembangan motorik anak normal lainnya mampu 
berlari menempuh jarak $1 \mathrm{~km} / \mathrm{jam}$, sedangkan anak berkebutuhan khusus mampu berjalan sejauh $1 \mathrm{~km}$. Sesuai dengan UUD/20/2003, dimana setiap warga negara memiliki hak yang sama untuk mengakses pendidikan serta mendapatkan pendidikan yang bermutu sehingga mampu meningkatkan potensi yang ada dalam dirinya(UndangUndang 2003). Dengan demikian, orang tua harus menyadari kebutuhan anaknya dan mampu menemukan sekolah yang sesuai dengan kebutuhan anak, terutama anak berkebutuhan khusus.

Anak sebagai individu dan sebagai warga masyarakat memiliki hak-hak yang perlu diterimanya, diantaranya adalah hak kesetaraan, hak hidup sehat, hak memenuhi perkembangan fisik dan mental yang sehat, hak pelayanan khusus jika diperlukan, hak mendapatkan pendidikan yang memadai dan bermutu yang mampu mengmebangkan segala potensinya, hak berlindung dari kejahatan dan eksploitasi serta hak untuk mendapatkan perlindungan dari penganiayaan yang dlakukan oleh teman sebaya, keluarga ataupun masyarakat(Nutbrown 2015).

Sesuai dengan kebijakan yang telah ditetapkan oleh pemerintah bahwa setiap lembaga pendidikan dianjurkan untuk mengikuti sistem inklusi(Permen 2009). Hal ini karena setiap anak memiliki hak yang sama sebagai warga negara, sehingga setiap anak berhak mendapatkan pendidikan yang bermutu untuk menunjang bakat anak(UndangUndang 2003). Baik anak normal ataupun anak yang berkebutuhan khusus, sehingga secara bersama-sama mereka mampu bersaing secara normal serta tidak ada alasan karena perbedaan sistem pendidikan yang diterima oleh anak.

Hadirnya sekolah inklusi membawa perubahan baru pada pemahaman masyarakat terkait anak berkebutuhan khusus. Bahwa mereka juga berhak mendapatkan pendidikan sebagaimana mestinya, serta tidak perlu mendapatkan sistem pendidikan khusus dalam bentuk sekolah luar biasa (SLB). Dimana, sekolah luar biasa ini merupakan lembaga pendidikan khusus anak berkebutuhan khusus, sehingga anak berkebutuhan khusus merasa bukan bagian dari masayarakat secara umum, karena SLB sebagai tembok pemisah antara anak berkebutuhan khusus dengan lingkungan sosialnya(Darma and Rusyidi 2015). Maka dari itulah sitsem inklusi hadir agar anak berkebutuhan khusus tidak merasa didiskreditkan karena tidak bisa masuk ke sekolah umum. Sehingga, Safa Islamic Preschool hadir untuk menjembatani anak berkebutuhan khusus dengan anak 
normal lainnya, karena seyogiyanya anak berkebutuhan khusus tidak bisa dipisahkan dari anak normal sebagai suatu komunitas(Hartadi, Dewantoro, and Junaidi 2019). Sehingga anak berkebutuhan khusus mampu belajar bersama dengan anak normal lainnya dalam satu atap, satu aturan dan satu kurikulum.

Sekolah inklusi merupakan lembaga pendidikan yang menerima semua anak dalam kondisi apapun, termasuk anak bekebutuhan khusus ringan, sedang, ataupun berat. Mereka secara bersama-sama ditempatkan di dalam kelas reguler dan mengikuti proses pembelajaran secara bersama-sama sepanjang hari(Baharun and Awwaliyah 2018). Sehingga, sekolah memiliki kewajiban untuk menyediakan program yang layak, sarana prasarana memadai, SDM yang sangat profesional, sehingga mendukung perkembangan anak(Wathoni 2013). Keseluruhan program yang dirancang oleh sekolah harus sesuai dengan kemampuan dan tahap perkembangan yang sedang dilalui oleh anak. Dengan kata lain, pihak sekolah yang harus menyesuaikan denga kebutuhan anak(Herawati 2010) bukan anak yang menyesuaikan dengan sekolah. Sehingga, anak berhasil menyelesaikan setiap tugas perkembangannya dengan baik.

Ada beberapa hal yang menjadi tujuan dibentuknya pendidikan inklusi(Depdiknas 2009). Pertama, untuk memberikan kesempatan yang sama kepada seluruh anak dalam mendapatkan pendidikan yang layak sesuai dengan kebutuhannya. Kedua, mengaplikasikan kebijakan wajib belajar. Ketiga, meningkatkan mutu pendidikan anakanak Indonesia, sehingga meminimalisir anak-anak putus sekolah. Keempat, menciptakan lingkungan belajar yang tidak diskriminatif dan menghargai keragaman.

Melalui tujuan di atas, pendidikan inklusi memiliki beberapa manfaat yang sangat berarti bagi anak berkebutuhan khusus, anak normal lainnya, serta masyarakat luas. Pertama, mampu meningkatkan rasa percaya diri anak berkebutuhan khusus. Kedua, anak memiliki kesempatan untuk menyesuaikan diri dalam menghadapi lingkungan sosial yang lebih luas. Ketiga, anak memiliki kesiapan dalam menghadapi lingkungan sosialnya dalam kondisi apapun. Sedangkan anak-anak secara umum mampu memahami, keterbatasan, keunikan dan kelebihan yang dimiliki oleh temannya, bahwa ia masih dalam proses belajar yang membutuhkan waktu sedikit lebih lama daripada dirinya. Dengan demikian, rasa empati dan simpati anak akan tumbuh dengan sendirinya, sehingga anak mampu mengembangkan keterampilan sosialnya dengan 
baik(Dewi 2017). Akan terbentuk karakter yang baik dalam diri anak, anak tidak akan mencela atas kekurangan temannya serta tidak akan memandang rendah temannya. Sedangkan manfat yang dapat dirasakan oleh masyarakat adalah terjadinya pergeseran pola pikir yang memandang anak berkebutuhan khusus merupakan anak cacat dan harus ditempatkan di lembaga pendidikan khusus ke pola pikir yang lebih baik, yaitu setiap anak memiliki hak yang sama dalam memperoleh pendidikan, baik anak berkebutuhan khusus ataupun anak secara umum(Pratiwi 2015). Dengan demikian, masyarakat akan menyediakan lingkungan yang mendukung dalam perkembangan anak berkebutuhan khusus.

Kurikulum merupakan bagian inti dalam suatu program pendidikan, karena kurikulum akan menentukan profil lulusan serta kemampuan anak. Serta sebagai sarana promosi sutau lembaga pendidikan, karena orang tua akan memilih lembaga yang dianggapnya baik untuk menitipkan anaknya, baik dari segi sarana prasarana, tenaga pendidik dan yang paling utama adalah kurikulum dan program yang dirancang oleh suatu lembaga pendidikan. Safa Green School mengembangkan kurikulum 2013 dan kurikulum Montessori yang bernafaskan Islam. Kedua kurikulum ini dikembangkan secara bersama untuk mencetak pendidik yang unggul dalam semua lini, baik dalam bidang kognitif ataupun keterampilan hidup.

Berhadapan dengan anak berkebutuhan khusus bukanlah hal yang mudah, terutama dalam mendidiknya. Untuk mencapai suatu tujuan pembelajaran, harus menggunakan pendekatan khusus serta strategi-streatgi tertentu seperti yang telah di bahasa pada bagian sebelumnya. Hal ini karena anak berkebutuhan khusus memiliki something spesial yang membedkannya dengan anak secara umum. Maka dari itulah, ada 7 prinsip yang bisa dikembangkan oleh pendidik agar mampu mewujudkan tujuan pembelajaran bagi anak berkebutuhan khusus(Abdullah 2013).Pertama, pendidik harus memberikan kasih sayang sepenuhnya kepada anak berkebutuhan khusus, misalnya tidak memanjakan anak dengan cara tidak memberikan semua yang ia mau, memperhatikan setiap kebutuhannya dan berusaha memenuhi semaksimal mungkin, serta tidak membebani tugas di luar kemampuan anak. Kedua, memberikan layanan individual yang memadai, artinya sangat penting kehadiran shadow teacher dalam proses pembelajaran anak berkebutuhan khusus, serta kurikulum dan jadwalpembelajaran yang bersifat fleksibel. Ketiga, memperhatikan kondisi mental 
anak dalam menerima pembelajaran, artinya pembelajaran diberikan ketika anak telah benar-benar siap atau sedang berada dalam mood yang baik. Keempat, pendidik harus selalu memotivasi anak berkebutuhan khusus. Hal ini lebih kepada metode pembelajaran dan pada saat melakukan evaluasi. Kelima, membiarkan anak belajar secara berkelompok. Dengan demikian, perilaku sosial anak akan terlatih serta meningkatkan kecakapan sosialnya serta rasa percaya dirinya. Keenam, memberikan keterampilan hidup. Hal ini untuk membantu anak dalam melanjutkan kehidupannya di masa mendatang. Ketujuh, penanaman dan penyempurnaan sikap anak berkebutuhan khusus. Hal ini karena anak berkebutuhan khusus berbeda dari anak secara umum, sehingga pendidik harus bekerja lebih ekstra agar sikap anak selalu stabil.

Asesmen merupakan pengumpulan informasi secara sistematis sesuai dengan konteks, misalnya untuk mengetahui efektivitas kurikulum, maka yang dikumpulkan adalah segala informasi yang berkaitan dengan kurikulum, begitu juga dengan efekivitas pembelajaran dan progres perkembangan peserta didik. Ada dua jenis asesmen yang bisa dilakukan untuk mengetahui progres perkembangan anak, yaitu asesmen kelas dan asesmen formatif. Kedua asesmen ini dignakan untuk mengetahui kelemahan-kelemahan dalam proses pembelajaran yang diterapkan dengan maksud untuk memperbaikinya di waktu berikutnya, sehingga anak menjadi lebih baik serta termotivasi untuk belajar (Yusuf 2015). Dengan demikian maka kehadiran asesmen sangat diperlukan dalam proses belajar mengajar.

Pendapat lain mengatakan bahwa penilaian merupakan suatu proses pengumpulan informasi secara menyeluruh pada anak usia dini, seperti motorik, kognitif, sosial, emosional, perilaku. Dilakukan secara sistematis, multidisiplin, dan didasarkan pada kemampuan dan perilaku keseharian anak (Gullo 2005). Sehingga, dapat disimpulkan bahwa asesmen merupakan suatu cara komprehensif untuk mengumpulkan informasi terkait segala hal yang berkaitan dengan peserta didik, untuk menunjang setiap hal dlam perkembangannya. Serta untuk mengumpulkan informasi apaka strategi dan metode pembelajaran sudah efektif atau belum yang ditunjukkan dengan kemajuan perkembangan anak.

Ada beberapa hal yang menjadi tujuan dilakukannya asesmen, sehingga asesmen menjadi sangat penting untuk dilakukan. Asesmen merupakan suatu kewajiban untuk dilakukan oleh pendidika kepada peserta didik, karena dengan asesmen, pendidik 
mampu melihat sacara luar dalam terkait informasi yang berkaitan dengan peserta didik. Maka tujuan dilakukannya asesmen adalah sebagai berikut (Gullo 2005):

Pertama, Untuk mengetahui dan memahami setiap perkembangan yang sedang dilalui oleh anak, sehingga pendidik mampu mengidentifikasi apakah anak membutuhkan waktu tambahan dalam pembelajaran atau tidak (pengajaran khusus). Kedua, Untuk mengetahui kelebihan dan kekurang anak dlam setiap bidang, karena setiap anak pasti memiliki kecenderungan yang berbeda dalam segala bidang. Apakah si A memiliki kemampuan lebih dalam membaca, si B dalam menghitung dan lain sebaginya. Sehingga, pendidik dapat menyusun strategi dan metode yang tepat untuk anak sesuai dengan potensi yang dimilikinya. Ketiga, Untuk mengukut keefektifan program yang telah disusun oleh pihak sekolah. Keempat, Untuk mengidentifikasi apakah anak mengalami hambatan dalam proses belajar dan membutuhakn layana khusus. Kelima, Untuk mendapakat umpan balik dari program yang telah dilakukan oleh anak, serta sebagai informasi dalam perbaikan program berikutnya(Mulyasa 2012).

Safa Islamic Preschool merupakan salah satu lembaga pendidikan untuk anak usia dini yang mengembangkan sekolah inklusi. Safa Islamic Preschool mengkombinasikan kurikulum 2013 dengan kurikulum Montessori dalam mengembangkan potensi anak. Kurikulum ini juga diterapkan pada anak berkebutuhan khusus, demikian juga dengan instrumen asesmennya. Anak berkebutuhan khusus ditangani langsung oleh shadow teacher yang merupakan seorang psikolog, karena anak didik yang berada di Safa merupakan jenis difabel disleksia, yaitu mengalami gangguan dalam masalah sosial emosi. Sehingga, anak membutuhkan guru pendamping seorang psikolog agar anak mampu memperbaiki sosial emosinya. Shadow teacher memiliki tanggung jawab sepenuhnya terhadap anak tersebut, baik dalam hal metode pembelajaran maupun dalam hal penilaiannya. Sehingga proses pembelajaran di dalam kelas benar-benar efektif, tidak menggangu anak yang lain serta tidak menimbulkan kecemburuan sosial. Karena anak didik yang lain memahami bahwa temannya (anak berkebutuhan khusus) membutuhkan waktu yang lama dalam proses belajarnya.

\section{METODE PENELITIAN}


Metode yang digunakan dalam penelitian ini adalah metode kualitatif dengan pendekatan studi kasus. Teknik pengumpulan data pertma, observasi langsung peserta didik, baik yang berkebutuhan khusus ataupun tidak berkebutuhan khusus di Safa Islamic Preschool serta shadow teacher dan guru-guru yang lain saaat proses pembelajaran berlangsung. Kedua, wawancara kepada kepala sekolah untuk informasi awal, guru kelas untuk melihat suduta pandang mereka terhadap anak berkebutuhan khusus, serta shadow teacher untuk mengetahui cara melakukan asesmen terhadap anak berkebutuhan khusus, kurikulum yang dirancang serta bagaimana perkembangannya dan ketiga, studi dokumen yaitu RPP, RKH, raport dan penilaian mingguan. Sedangkan teknis analisi ata yang digunakan mengacu pada konsep konsep Miles dan Hubermen (Idrus 2009), yaitu pertama, reduksi data, setiap informasi yang diperoleh oleh peneliti dipilih dan dipilah sesuai dengan kebutuhan peneliian. Kedua, penyajian data, data yang telah dipilih kemudian di susun dalam bentug paragraf danketiga penarikan kesimpulan atas hasil perolehan data sera melakukan verifikasi terhadap data yang telah diperoleh ole peneliti.

\section{HASIL PENELITIAN DAN PEMBAHASAN}

Safa Islamic Preschool merupakan lembaga pendidikan dengan sisem pendidikan inklusi. Proses penerimaan siswa baru salah satunya adalah melakukan asesmen di awal pendaftaran peserta didik, sehingga anak harus ikut saat orang tua mendaftarkannya. Pada saat pendaftaran itulah pihak sekolah melakukan deteksi dini terhadap anak, dan menemukan beberapa ada dengan something spesial. Hal ini karena tidak semua orang tua mengetahui anaknya berkebutuhan khusus, atau orang tua memang menyembunyikannya kondisi anak yang sebenarnya. Melalui asesmen awal ini, pihak sekolah menyediakan shadow teacher sesuai dengan kebutuhan anak.

Setelah melakukan observasi, Safa Islamic Preschool saat ini memiliki dua peserta didik berkebutuhan khusus dengan jenis gangguan yang sama, yaitu Diseleksia. Disleksia merupakan suatu gangguan yang menyebabkan anak kehilangan kemampuan dalam hal membaca, menulis ataupun berbicara(Thompson 2012). Selain itu, anak-anak dengan Disleksia akan susah fokus, suka mengulang-ngulang kata namun tidak jelas kata yang diucapkan, baik karena dikurangi hurufnya atau terbolak-balik hurufnya. 
Selain itu, anak juga mengalami keterbelakangan emosi dan sosialnya, anak menarik diri dari lingkungan sosialnya karena merasa terancam.

Anak dengan disleksia sangat membutuhkan shadow teacherdalam proses belajarnya, sehingga anak mampu mengembangkan segala aspek yang ada dalam dirinya, baik aspek kognitif, afektif ataupun psikomotorik. Sehingga, Safa Islamic Preschool memilih seorang psikolog untuk menjadi shadow teacheranak berkebutuhan khusus tersebut, karena seorang psikolog dirasa mampu untuk mengetahui kondisi batin anak dengan Disleksia. Sehingga anak mampu mengikuti pembelajaran di kelas dengan baik.

Oleh karena Safa Islamic Preschool mengembangkan konsep inklusi, yang artinya tidak ada perlakuan eksklusif terhadap anak berkebutuhan khusus, maka anak berkebutuhan khusus juga mengikuti kurikulum secara umum yang telah dirancang oleh pihak sekolah. Namun sedikit dimodifikasi sesuai dengan kemampuan dan kebutuhan anak, yaitu bersifat adaptif(Asiyah 2018). Artinya, setiap kegiatan pembelajaran harus disesuaikan dengan potensi dan hambatan anak berkebutuhan khusus, sehingga anak mampu menyelesaikan setiap aktivitas yang dilakukan pada saat proses pembelajaran. Hal ini karena perkembangan kognitif, emosi, sosial dan jasmani anak sebagai acuan dalam penyusunan kurikulum(Patmonodewo 2003). Dengan kata lain KI (kompetensi inti) dan KD (kompetensi dasar) yang terdapat dalam kurikulum lebih di sederhana untuk anak berkebutuhan khhusus dibanding anak secara umum. Hal ini dapat dilihat melalui RPM (rencana pembelajaran mingguan) atau RKH (rencana kegiatan harian).

Hal ini karena, kurikulum akan sangat mempegaruhi proses belajar mengajar serta berdampak signifikan terhadap mutu pendidikan. Selain kurikulum, input siswa, tenaga pendidik juga memiliki peran vital dalam proses belajar mengajar, demikian juga sarana prasarana, manajemen sekolah serta peran lingkungan, yaitu seluruh keluarga, sekolah serta masyarakat(Salim 2010). Apabila salah satu dari kompenen ini berubah, maka seluruh komponen akan mengalami perubahan. Misalnya, anak berkebutuhan khusus di dalam kelas tidak hanya terdapat satu jenis something spesial, melainkan tiga jenis yang berbeda. Maka sudah tentu kurikulum harus dimodifikasi sesuai dengan kemampuan serta kebutuhan ketiga anak berkebutuhan khusus tersebut. 
Kemudian, apabila perlu menambah shadow teacher maka hal itu perlu dilakukan, begitu juga sarana dan prasarana yang ada, harus disesuaikan dengan kebutuhan anak.

Awalnya, anak berkebutuhan khusus yang ada di Safa memiliki shadow teacher sendiri yang dipilihkan oleh orang tuanya, sehingga shadow teacher tersebut tidak hanya mendampingi anak di sekolah, melainkan juga di rumah. Namun, setelah anak masuk TK B shadow teacher tersebut mengundurkan diri karena suatu hal, sehingga orang tua anak meminta pihak sekolah menyediakan shadow teacher untuk anaknya. Berbekal asesmen awal yang dilakukan oleh pihak sekolah terhadap peserta didik baru, maka pihak sekolah memutuskan seorang psikolog yang paling tepat dalam mendampingi proses belajar anak. Hal ini karena secara umum anak mengalami keterbelakangan emosi dan sosialnya.

Sebelum didampingi oleh seorang psikolog, anak berkebutuhan khusus tersebut benar-benar tidak bisa berinteraksi dengan teman-temannya ataupun dengan para guru yang lain di dalam kelas. Misalnya, ia tidak mau didekati oleh guru lain selain shadow teacher-nya, ia tidak mau duduk di bangku bersama teman-temannya. Kondisi ini membuat teman-temannya menjadi takut dan menjauhi anak. Namun, setelah anak berkebutuhan khusus ini didampingi oleh seorang psikolog, maka terjadi perubahan yang sangat signifikan terhadap perkembangan emosi dan sosialnya. Anak yang pada awalnya tidak mau didekati oleh teman-temannya bahkan guru kelas, saat ini mampu berinteraksi dengan baik di dalam kelas. Anak mampu menyapa dan memberi salam kepada guru ataupun teman-temannya yang lain. Anak mampu berbagi barang miliknya, baik mainan ataupun makanan. Anak mampu melakukan kegiatan sebagaimana anak secara umum, walaupun tidak semua kegiatan di dalam kelas bisa diikuti dengan baik. Ada empat jenis kegiatan yang dilakukan di dalam kelas setiap harinya, dan anak berkebutuhan khusus hanya mampu melakukan 1 atau dua kegiatan saja setiap harinya. Bahkan ketika anak sedang mengalami badmood, anak tidak mau melakukan kegiatan kelas sama sekali, walaupun dipaksa oleh shadow teacher anak tetap tidak bisa melakukannya. Nah, disinilah shadow teacher diuji, bagaimana ia tetap bisa melakukan kegiatan yang bermanfaat bagi perkembangannya walaupun kegiatan tersebut di luar kegiatan kelas. Artinya, shadow teacher harus kreatif menggangi kegaiatan kelas dengan kegiatan lain yang memiliki tujuan pembelajaran yang sama, kompetensi dasar yang ada dalam kurikulum dapat tercapai oleh anak. 
Pada dasarnya, orang tua anak berkebutuhan khusus tersebut tidak menuntut terlalu banyak dari anaknya, terlebih dalam hal perkembangan kognitifnya. Orang tua meminta shadow teacher untuk lebih fokus pada perkembangan sosial emosionalnya, namun shadow teacher tentu berharap anak juga mampu megalami perkembangan yang baik dalam ranah kognitifnya. Maka dari itulah, shadow teacher harus menyiapkan beberapa strategi agar anak mengalami perkembangan yang maksimal sesuai dengan kemampuannya dalam segal bidang.

Ada banyak strategi yang dilakukan oleh shadow teacher dalam menangani anak berkebutuhan khusus. Pertama, seperti yang dilakukan oleh SD 1 Negeri Tanjung dalam hasil penelitian yang dilakukan oleh Agung Nugroho, yaitu proses pembelajaran yang dilakukan mengunakan metode klasikal, dimana anak berkebutuhan khusus berada dalam satu kelas secara bersama-sama dengan anak secara umum(Nugroho and Mareza 2016). Melalui metode ini, anak berkebutuhan khusus akan belajar bersosialisasi di lingkungan yang lebih luas setelah lingkungan keluarga. Sosial emosi anak akan mudah terkontrol karena anak belajar dari teman-temannya melalui bimbingan shadow teacher. Demikian juga anak secara umum, mereka akan memahami bahwa temannya berbeda, bahwa temannya masih dalam proses belajar dan membutuhkan waktu yang sedikit lebih lama dibanding dirinya.

Kedua, shadow teacher mengamati anak dengan baik, apakah anak dalam kondisi baik atau buruk. Ketika anak dalam kondisi buruk, maka ia sama sekali tidak bisa mengikuti proses pembelajaran di kelas. Sehingga, shadow teacher mengajak anak bermain untuk memperbaiki mood-nya. Dengan demikian, shadow teacher bisa memasukkan sub tema pembahasan pada hari tersebut pada permainan yang sedang dilakukan oleh anak.

Ketiga, shadow teacher bersikap tegas kepada anak. Artinya, anak tidak selalu mendapatkan apa yang dia inginkan, sehingga anak tidak tumbuh menjadi pribadi yang manja. Misalnya, anak tidak bisa minum kecuali menggunakan sedotan, sedangkan ia lupa membawanya dari rumah. Sehingga, shadow teacher memberinya minum menggunakan gelas, anak tidak mau meminumnya dan shadow teacher pun tidak mau memaksanya. Shadow teacher hanya memberi dua pilihan, minum menggeunakan gelas atau tidak usah minum susu. Tindakan semacam ini perlu dilakukan kepada anak, unuk 
membentuk kepribadian anak, bahwa tidak setiap hal yang ia inginkan bisa ia dapatkan. Serta ia harus memahami bahwa setiap perbuatan ada konsekuensinya.

Keempat, shadow teacher melakukantarik ulur dalam proses pembelajaran sosial emosionalnya. Artinya, tidak memaksakan kehndaknya kepada anak, biarkan anak merajuk. Misalnya, anak marah dan memukul shadow teacher, kemudian shadow teacher membalas ukulan anak, begitu seterusnya sampai anak terpancing emosinya. Pada saat itu, shadow teacher harus meninggalkan anak sendirian agar emosinya tenang, biasanya anak akan mengejar dan merajuk meminta maaf. Shadow teacher tidak langsung memaafkan anak tersebut untuk proses pembelajaran. Hal ini agar anak tidak melakukan suatu perbuatan yang tidak ingin orang lain lakukan terhdapnya.

Kelima, ketika anak berbicara, shadow teacher akan meminta untuk mengulanginya dengan suara nyaring, kemudian shadow teacher memperjelas perkataan anak dan meminta anak untuk mengulanginya kembali. Hal ini dilakukan agar anak memahami perkataannya dengan baik, mana yang benar dan mana yang salah. Shadow teacher harus selalu mendorong anak untuk selalu berbicara(Santi 2009), hal ini untuk menambah perbendaharaan kosa-kata anak, dan akan mempengaruhinya dalam hal membaca.

Melalui paparan di atas, dapat disimpulkan bahwa kehadiran psikolog merupakan solusi tepat yang telah ditentukan oleh pihak sekolah untuk mendampingi anak berkebutuhan khusus dengan jenis disleksia. Hal ini karena anak telah mengalami perkembangan yang sangat baik dalam segi sosial emosionalnya. Serta strategi yang digunakan merupakan strategi yang memenuhi prasyarat untuk menjadi shadow teacher anak usia dini menurut Solehudin(Suyanto 2005), yaitu sesuai dengan karakteristik anak, bersifat terpadu, menyediakan sejumlah alternatif kegiatan untuk dilakukan oleh anak, memberikan ruang kepada anak untuk berinteraksi dengan teman-teman sebaya dan guru kelas yang lain, fleksibel dan tidak terstruktur serta bermain sambil belajar. Dengan demikian, dapat dikatakan bahwa Safa Islamic Preschool benar-benar menerapkan sistem pendidikan inklusi secara nyata, bukan hanya sekedar perencaanaan. Karena banyak sekali lembaga pendidikan yang mengaku menerapkan sistem inklusi, namun faktanya di lapangan mereka sama sekali tidak menunjukkan prasyarat membangun pendidikan inklusi, misalnya tidak bersedia menydiakan shadow 
teacher bagi anak berkebutuhan khusus, karena masalah anggaran. Selain itu, lemahnya kemampuan guru dalam memahami karakteristik dan kebutuhan anak berkebutuhan khusus, serta rendahnya pengetahuan tentang metode dan prosedur dalam pelaksaan sistem pendidikan inklusi. Pada dasarnya, untuk membangun lembaga pendidikan inklusi harus menyiapkan beberapa hal penting. Seperti, kurikulum yang sesuai dengan kebutuhan anak, insrumen penilaian, strategi dan metode pembelajaran serta seorang shadow teacher. Tidak serta merta menerima anak berkebutuhan khusus secara spontan ketika ada peserta didik yang mendaftar, melainkan harus menyiapkan beberapa hal penting di atas, agar ruh dari lembaga pendidikan inklusi benar-benar ada, bukan hanya sebagai label saja, sekolah inklusi.

Memang bukan hal yang mudah dalam melakukan asesmen terhadap anak berkebutuhan khusus, hal ini karena anak berkebutuhan khusus memiliki standarisasi berbeda dari anak-anak secara umum. Lembaga pendidikan inklusi tentu tidak akan mengalami masalah dalam melakukan asesmen terhadap anak berkebutuhan khusus, karena telah dirancang sejak awal semester oleh kepala sekolah. Serta dilakukan langusng oleh shadow teacher yang telah memahami anak lebih jauh daripada orang lain.

Ada beberapa penilaian yang dilakukan oleh Safa Islamic Preschool untuk mengetahui kemajuan perkembangan peserta didik, yaitu catatan anekdot, hasil karya, cheklis dll. Penilaian ini dilakukan kepada anak secara umum ataupun kepada anak berkebutuhan khusus, seperti yang telah dijelaskan di atas bahwa KD lebih disederhanakan utuk anak berkebutuhan khusus. Selain untuk mengetahui kemajuan perkembangan anak, juga ssebagai sarana komunikasi anatara guru dan orang tua peserta didik. Karena penilaian diserahkan setiap minggu kepada orang tua, apa saja yang telah dicapai oleh anak sesuai dengan kurikulum 2013 dan Montessori. Mencakup nilai agama dan moral, kognitif, psikomotorik, sosial emosi, bahasa, seni, keterampilan hidup, percoban, matematika dan sensosial. Dalam raport mingguan ada kolom catatan yang bisa disampainkan oleh guru terhadap kemajuan anak, serta kolom untuk orang tua kepada guru terkait prkembangan ataupun proses belajar anak.

Khusus anak berkebutuhan khusus penilaiannya dilakukan sesuai dengan kondisi anak. Artinya, anak dilakukan penilaian ketika anak melakukan kegiatan di dalam kelas 
atau kegiatan lain yang menunjang kemajuan perkembangan anak. Walaupun anak berkebutuhan khusus mengalami keterlambatan daripada anak-anak lainnya, namun secara umum anak berkebutuhan khusus dikatakan mampu berkembang dengan baik. Misalnya, anak mampu mengikuti instruksi guru untuk memotong dan menempel sesuai dengan gambar (kognitif), mampu melipat baju (keterampilan hidup) dan lain sebagainya.

Penilaian yang dilakukan kepada anak harus secara sistematis seusuai dengan prosedur yang telah ada, sehingga hasil dari penilaian dapat dikatakan valid dan reliabel untuk mengukur kemajuan perkembangan anak. Beberapa lembaga pendidikan masih belum sadar akan pentingnya kemajuan afekif anak, sehingga hanya melakukan penilaian terhadap perkembangan kognitif saja, waluapun demikian masih ada beberapa lembaga lainnya yang mengembangkan kedua penilaian tersebut, yaitu afektif dan kognitif(Nah and Kwak 2011). Seperti halnya yang dilakukan oleh Safa yang mengembangkan kedua penilaian tersebut. Hal ini karena Safa sadar bahwa kedua hal tersebut merupakan satu kesatuan yang tak dapat dipisahkan dan saling mendukung satu sama lain untuk kesempurnaan kehidupan anak di masa mendatang.

Beberapa hal yang perlu diperhatikan dalam melakukan penilaian kepada anak berkebtuhan khusus adalah harus mempertimbangkan kriteria yang telah ditetapkan oleh sekolah, apakah benar-benar cocok dengan kondisi anak atau belum, mepertimbangkan karakteristik individu serta latar belakang atau profil pribadi anak dan keluarganya(Hussu and Strle 2010). Hal ini dilakukan untuk menghindari bias, karena secara umum penilaian untuk anak berkebutuhan khusus masih snagat tabu di kalangan masyarakat, sehingga beberapa lembaga pendidikan masih kurang lihai dalam melakukan penilaian terhadap anak berkebutuhan khusus. Sehingga mereka melakukan penilaian tidak sesuai dengan prosedur yang ada.

\section{SIMPULAN DAN SARAN}

Berdasarkan hasil penelitian dan pembahasan di atas dapat disimpulkan bahwa lembaga pendidikan yang mengembangkan sistem pendidikan inklusi harus sesuai dengan prosedur, baik dalam penyususnan kurikulum strategi pembelajaran serta teknik-teknil penilaian. Dari keseluruhan itu, harus disesuaikan dengan kemampuan dan hambatan anak berkebutuhan khusus. 
Saran bagi peneliti hendaknya membahas lebih jauh bagiamna dan cara-cara mengembangkan sistem pendidikan inklusi, cara penyusunan RPPM lebih detail, serta melakukan wawancara kepada orang tua jika diperlukan.

\section{REFERENSI}

Abdullah, Nandiyah. 2013. "Mengenal Anak Berkebutuhan Khusus." Magistra 25 (86): 1. Asiyah, Dewi. 2018. "Dampak Pola Pembelajaran Sekolah Inklusi Terhadap Anak Berkebutuhan Khusus." Prophetic 1 (01): 69-82. http://www.syekhnurjati.ac.id/jurnal/index.php/prophetic/article/view/3480.

Baharun, Hasan, and Robiatul Awwaliyah. 2018. "Pendidikan Inklusi Bagi Anak Berkebutuhan Khusus Dalam Perspektif Epistimologi Islam.” Program Studi PGMI 5 (1): 58-71. http://ejournal.uinsuka.ac.id/tarbiyah/index.php/goldenage/article/download/1929/1408/.

Darma, Indah Permata, and Binahayati Rusyidi. 2015. "Pelaksanaan Sekolah Inklusi Di Indonesia." Prosiding Penelitian Dan Pengabdian Kepada Masyarakat 2 (2): 223-27. https://doi.org/10.24198/jppm.v2i2.13530.

Depdiknas. 2009. Standar Pendidikan Anak Usia Dini. Jakarta: BSNP.

Dewi, Nurul Kusuma. 2017. "Manfaat Program Pendidikan Inklusi Untuk AUD.” Jurnal Pendidikan Anak, 1-10.

Efendi, Mohammad. 2006. Pengantar Psikopedagogik Anak Berkelainan. Jakarta: PT Bumi Aksara.

Faradina, Novira. 2016. "Penerimaan Diri Pada Orang Tua Yang Memiliki Anak Berkebutuhan Khusus.” Jurnal Elektronik Psikologi Universitas Mulawarman 4 (4): 386-96. http://ejournal.psikologi.fisip-unmul.ac.id/site/wpcontent/uploads/2016/03/ejournal_novira faradina (ONLINE) (03-17-16-07-16-01).pdf.

Gullo, Dominic F. 2005. Understanding Assessment and Evaluations in Early Childhood Education. New York: Teachers College Press.

Hartadi, Dewi Rahmawati, Dimas Arif Dewantoro, and Ahsan Romadlon Junaidi. 2019. "Kesiapan Sekolah Dalam Melaksanakan Pendidikan Inklusif Untuk Anak Berkebutuhan Khusus Di Sekolah Dasar" 5 (November): 90-95.

Herawati, Nenden Ineu. 2010. "Pendidikan Inklusif." Journal of Chemical Information and Modeling 12 Suppl 1 (9): 1-29. https://doi.org/10.1007/978-1-4614-7990-1.

Hussu, Amelija Mozetič, and Marko Strle. 2010. "The Assessment of Children with Special Needs." Procedia - Social and Behavioral Sciences 2 (2): 5281-84. https://doi.org/10.1016/j.sbspro.2010.03.861.

Idrus, Muhammad. 2009. Metode Penelitian Ilmu Sosial: Pendektan Kualitatif Dan Kuantitatif. Kedua. Jakarta: Erlangga.

Mulyasa, H. E. 2012. Manajemen PAUD. Bandung: Remaja Rosdakarya.

Nah, Kwi Ok, and Jung In Kwak. 2011. "Child Assessment in Early Childhood Education and Care Settings in South Korea.” Asian Social Science 7 (6): 66-78. https://doi.org/10.5539/ass.v7n6p66.

Nugroho, Agung, and Lia Mareza. 2016. "Jurnal Pendidikan Dasar PerKhasa Volume 2, Nomor 2, Oktober 2016 Modeldan Strategi Pembelajaran Anak Berkebutuhan Khususdalam Setting Pendidikan Inklusi” 2.

Nutbrown, Cathy dan Peter Clough. 2015. Pendidikan Anak Usia Dini: Sejarah, Filosofi Dan Pengalaman. Yogyakarta: Pustaka Pelajar. 
Patmonodewo, Soemiarti. 2003. Pendidikan Anak Prasekolah. Jakarta: Rineka Cipta.

Permen, Nomor 70. 2009. Pendidikan Inklusifbagi Peserta Didikyan Memiliki Kelainandan Memiliki Potensi Kecerdasandan/atau Bakat Istimewa.

Pratiwi, Jamilah Candra. 2015. "Sekolah Inklusi Untuk Anak Berkebutuhan Khusus :

Tanggapan Terhadap Tantangan Kedepannya." Prosiding Seminar Nasional Pendidikan

"Meretas Sukses Publikasi Ilmiah Bidang Pendidikan Jurnal Bereputasi," no.

November: 237-42.

http://jurnal.fkip.uns.ac.id/index.php/pip/article/download/7725/5551.

Salim, Abdul. 2010. "Pengembangan Model Modifikasi Kurikulum Sekolah Inklusif Berbasis

Kebutuhan Individu Peserta Didik.” Jurnal Pendidikan Dan Kebudayaan 16 (7): 21. https://doi.org/10.24832/jpnk.v16i7.504.

Santi, Danar. 2009. Pendidikan Anak Usia Dini: Antara Teori Dan Prakik. Jakarta: Indeks.

Smart, Aqila. 2006. Anak Cacat Bukan Kiamat: Metode Pembelajaran \& Terapi Untuk Anak Berkebutuhan Khusus. Yogykarta: Ar-Ruzz Media.

Suyanto, Slamet. 2005. Dasar-Dasar Pendidikan Anak Usia Dini. Yogyakarta: Hikayat.

Thompson, Jenny. 2012. Memahami Anak Berkebutuhan Khusus. tt: Esensi.

Undang-Undang, Nomor 20. 2003. SISTEM PENDIDIKAN NASIONAL.

Undang-Undang, Nomor 8. 2016. Penyandang Disabilitas.

Wathoni, Kharisul. 2013. "Implementasi Pendidikan Inklusi Dalam Pendidikan Islam."

Ta'allum: Jurnal Pendidikan Islam 1 (1). https://doi.org/10.21274/taalum.2013.1.01.99109.

Wati, Ery. 2014. "Manajemen Pendidikan Inklusi Di Sekolah Dasar Negeri 32 Kota Banda Aceh." Jurnal Ilmiah Didaktika 14 (2): 368-78. https://doi.org/10.22373/jid.v14i2.508.

Yusuf, Muri. 2015. Asesmen Dan Evaluasi Pendidikan: Pilar Penyedia Informasi Dan Kegiatan Pengendalian Mutu Pendidikan. Jakarta: Kencana. 